\title{
Comparative analysis of bacterial communities associated with healthy and diseased corals in the Indonesian sea
}

\author{
Wuttichai Mhuantong Equal frst author, ${ }^{1}$, Handung Nuryadi ${ }^{\text {Equal first author, }}{ }^{2}$, Agus Trianto ${ }^{2}$, Agus Sabdono ${ }^{2}$, Sithichoke \\ Tangphatsornruang $^{3}$, Lily Eurwilaichitr ${ }^{1}$, Pattanop Kanokratana ${ }^{\text {Corresp., } 1}$, Verawat Champreda ${ }^{1}$ \\ 1 Biorefinery and Bioproduct Technology Research Group, National Center for Genetic Engineering and Biotechnology, Pathum Thani, Thailand \\ 2 Faculty of Fisheries and Marine Science, Diponegoro University, Semarang, Indonesia \\ 3 National Omics Center, National Center for Genetic Engineering and Biotechnology, Pathum Thani, Thailand \\ Corresponding Author: Pattanop Kanokratana \\ Email address: pattanopk@biotec.or.th
}

Coral reef ecosystems are impacted by climate change and human activities, such as increasing coastal development, overfishing, sewage and other pollutant discharge, and consequent eutrophication, which triggers increasing incidents of diseases and deterioration of corals worldwide. In this study, bacterial communities associated with four species of corals: Acropora aspera, Acropora formosa, Cyphastrea sp., and Isopora sp. in the healthy and disease stages with different diseases were compared using tagged $16 \mathrm{~S}$ rRNA sequencing. In total, 59 bacterial phyla, 190 orders, and 307 genera were assigned in coral metagenomes where Proteobacteria and Firmicutes were pre-dominated followed by Bacteroidetes together with Actinobacteria, Fusobacteria, and Lentisphaerae as minor taxa. Principal Coordinates Analysis (PCoA) showed separated clustering of bacterial diversity in healthy and infected groups for individual coral species. Fusibacter was found as the major bacterial genus across all corals. The lower number of Fusibacter was found in $A$. aspera infected with white band disease and Isopora sp. with white plaque disease, but marked increases of Vibrio and Acrobacter, respectively, were observed. This was in contrast to $A$. formosa infected by a black band and Cyphastrea sp. infected by yellow blotch diseases which showed an increasing abundance of Fusibacter but a decrease in WH1-8 bacteria. Overall, infection was shown to result in disturbance in the complexity and structure of the associated bacterial microbiomes which can be relevant to the pathogenicity of the microbes associated with infected corals. 
1 Comparative analysis of bacterial communities associated with healthy and diseased corals

2 in the Indonesian sea

3 Wuttichai Mhuantong ${ }^{1}$, Handung Nuryadi², AgusTrianto ${ }^{2}$, Agus Sabdono ${ }^{2}$, Sithichoke

4 Tangphatsornruang ${ }^{3}$, Lily Eurwilaichitr ${ }^{1}$, Pattanop Kanokratana ${ }^{1}$, Verawat Champreda ${ }^{1}$

$5 \quad{ }^{1}$ Biorefinery and Bioproduct Technology Research Group, National Center for Genetic

6 Engineering and Biotechnology, Thailand Science Park, Khlong Luang, Pathum Thani 12120,

7 Thailand

$8 \quad{ }^{2}$ Faculty of Fisheries and Marine Science, Diponegoro University, Semarang 50275, Indonesia

$9{ }^{3}$ National Omics Center, National Center for Genetic Engineering and Biotechnology, Thailand

10 Science Park, Khlong Luang, Pathum Thani 12120, Thailand

$11 *$ Corresponding author

12 Pattanop Kanokratana ${ }^{1}$

13 Thailand Science Park, Khlong Luang, Pathum Thani 12120, Thailand

14 E-mail: pattanopk@,biotec.or.th 


\section{Abstract}

Coral reef ecosystems are impacted by climate change and human activities, such as increasing coastal development, overfishing, sewage and other pollutant discharge, and consequent eutrophication, which triggers increasing incidents of diseases and deterioration of corals worldwide. In this study, bacterial communities associated with four species of corals: Acropora aspera, Acropora formosa, Cyphastrea sp., and Isopora sp. in the healthy and disease stages with different diseases were compared using tagged 16S rRNA sequencing. In total, 59 bacterial phyla, 190 orders, and 307 genera were assigned in coral metagenomes where Proteobacteria and Firmicutes were pre-dominated followed by Bacteroidetes together with Actinobacteria, Fusobacteria, and Lentisphaerae as minor taxa. Principal Coordinates Analysis (PCoA) showed separated clustering of bacterial diversity in healthy and infected groups for individual coral species. Fusibacter was found as the major bacterial genus across all corals. The lower number of Fusibacter was found in A. aspera infected with white band disease and Isopora sp. with white plaque disease, but marked increases of Vibrio and Acrobacter, respectively, were observed. This was in contrast to $A$. formosa infected by a black band and Cyphastrea sp. infected by yellow blotch diseases which showed an increasing abundance of Fusibacter but a decrease in WH1-8 bacteria. Overall, infection was shown to result in disturbance in the complexity and structure of the associated bacterial microbiomes which can be relevant to the pathogenicity of the microbes associated with infected corals. 
37 Coral reefs contain important ecological space harboring a diversity of marine organisms and

represents the core element of the complex marine ecosystem. Southeast Asia contains the largest area of coral reefs accounting for $34 \%$ of the world's total (Wilkinson, 2008). The reefs play crucial roles in ecology such as protecting the coastline from erosion, providing habitats for marine organisms, and supplying nutrients for the complex marine food chains. The coral reef ecosystem is estimated to provide USD 29.8 billion per year of economic benefit worldwide from various sectors, e.g. fisheries, tourisms, coastal protection, and biodiversity (Cesar et al., 2003). From a scientific point of view, corals are also considered a rich source of unique and unexplored biosynthetic products (Radjasa et al., 2011). In this ecosystem, diverse symbioses exist with complex interactive dependences between corals and associated communities of eukaryotic and prokaryotic microorganisms (Blackall et al., 2015). For example, dinoflagellate endosymbionts, Symbiodiniaceae (LaJeunesse et al. 2018)utilizes light energy (Brodersen et al., 2014) and secrete fixed carbon to the coral host (Burriesci et al., 2012). This symbiosis creates a highly complex and unique ecosystem.

In the last few decades, coral reefs have been facing world-wide crisis related to coral degradation driven by complicated phenomena including anthropogenic stresses and natural factors (Wilkinson, 2008). It is estimated that the world has collectively lost $19 \%$ of the original area of coral reefs while $15 \%$ are seriously endangered with expected damage within the next 10-20 years and 20\% are under threat of loss in 20-40 years (Wilkinson, 2008). Degradation of coral reefs ecosystem can lead to massive loss of marine biodiversity. One of the serious threats to coral reefs ecosystem comes from various coral diseases (Harvell et al., 2007; Hughes et al., 2003). The occurrence of these diseases has been increasing dramatically during the last decade

\section{Introduction}


59 due to the rising sea-water temperature as a consequence of climate change (Rosenberg \& Ben-

60 Haim, 2002). Many of these diseases are prevalent in reef-builder corals (Order Scleractinia),

61 leading to the deterioration of entire reefs structures (Harvell et al., 2007; Rosenberg et al., 62 2007). Among them, black band, white band, white plague, white pox, brown band, red band, 63 and yellow band syndromes are the main threats on corals in the Caribbean, Indo-Pacific, and 64 Great Barrier Reef.

65 Coral diseases can be triggered by infection of pathogenic agents involving specific groups of 66 bacteria, fungi, and viruses (Bourne et al., 2009; Harvell et al., 2007). Displacement of primary 67 symbiotic microorganisms with other members has been shown to be related to the appearance of the disease signs. For example, the yellow blotch disease is caused by infection of Vibrio spp. which targets endosymbiotic zooxanthellae rather than the coral tissue, resulting in a decrease in chlorophyll concentration (Cervino et al., 2004a). Bacteria are considered as the major infectious microorganisms in corals. So far, only a limited number of bacteria have been isolated and identified as causative agents of coral diseases by Koch's postulates, including cyanobacteria for black band disease, Vibrio sp and Acrobacter sp for white band disease, Vibrio spp for yellow blotch disease and Serratia marcescens for white pox (Sheridan et al., 2013). However, the symbiotic nature of bacteria to corals makes them unculturable using current isolation techniques. Therefore, identification of the causative microbes by conventional culturedependent approaches may not be able to give the complete scenario of coral associated microbial communities upon infection. markers allows direct study of the uncultured microorganisms, which can make up to $99 \%$ of the total diversity in many ecosystems (Schloss \& Handelsman, 2005). Several studies have shown 
82 that culture-independent approaches based on bacterial molecular markers have been performed

83 to explore the microbial communities associated with healthy and corals under stresses in the

84 Caribbean and Indo-Pacific regions and their roles in pathogenesis (Gignoux-Wolfsohn \&

85 Vollmer, 2015; Meyer et al., 2017; Pootakham et al., 2018). However, variation in the taxonomic

86 composition of the microbial consortia related to existing coral diseases can depend on different

87 geographical, seasonal, and physical factors of the coral habitats (Sokolow, 2009; Woo et al.,

88 2017). In order to gain more information on the roles of uncultured bacteria on coral diseases in

89 Southeast Asia, the bacterial communities associated with corals collected from Indonesian sea,

90 which is considered one of the world's most important coral habitat, in healthy and diseased

91 stages affected by black band disease (BBD), white band disease (WBD), white plaque disease

92 (WPD), and yellow blotch disease (YBD) were explored in this study using tagged 16S rRNA

93 sequencing on a next-generation sequencing platform. Our work compares coral-associated

94 bacteria in different host species and shows shifts in the bacterial community structure during the

95 diseased stage. Our findings expand the current understanding on the microbiology of these

96 prevalent coral diseases.

\section{Materials and Methods}

\section{Sample collection and DNA extraction}

99 Coral specimens were taken from the Indonesian sea in Central Java (Cemara Kecil (S 0549'

$10057,7^{\prime \prime}$ E $\left.110^{\circ} 22^{\prime} 50,5^{\prime \prime}\right)$ and Karimunjawa (S $05^{\circ} 50^{\prime} 12,99^{\prime \prime}$ E $110^{\circ} 25^{\prime} 14,1$ '”)(Supplementary

101 Fig. S1) during September, 2015 from a depth of about 3 - $5 \mathrm{~m}$, with the permission from the

102 Balai Taman Nasional Karimunjawa (the approval number 934 /BTNKJ-1.6 /SIMAKSI /2015).

103 Triplicate samples (10 g each) of fragments from healthy and lesion fragments from diseased 
104 corals were collected from individual coral species including Acropora aspera, Acropora

105 Formosa, Cyphastrea sp., and Isopora sp. Healthy and infected coral were collected from

106 different colonies of same species on same reefs. Coral fragments were placed in sterile bottles

107 filled with seawater obtained from the same sampling area during transportation. The samples

108 were rinsed using sterilized sea water and preserved at $-80^{\circ} \mathrm{C}$ upon arrival at the laboratory

109 (Wegley et al., 2007). Physicochemical properties of the seawater including temperature,

110 salinity, dissolved oxygen and pH were measured using Lutron YK-2005WA (Lutron Electronic

111 Enterprise, Taipei, Taiwan).

112 The coral specimens were grounded in a mortar prior to metagenomic DNA extraction using the

113 SDS-based DNA extraction procedure (Zhou et al., 1996), with slight modifications

114 (Kanokratana et al., 2004). Briefly, $1 \mathrm{~g}$ of grounded sample was mixed vigorously for $30 \mathrm{~min}$ at

$11537{ }^{\circ} \mathrm{C}$ with $2.7 \mathrm{ml}$ DNA extraction buffer (100 mM Tris-HCl (pH 8.0), $100 \mathrm{mM}$ sodium EDTA

116 (pH 8.0), $100 \mathrm{mM}$ sodium phosphate (pH 8.0), $1.5 \mathrm{M} \mathrm{NaCl}, 1 \%(\mathrm{wt} / \mathrm{vol})$

117 cetyltrimethylammonium bromide $(\mathrm{CTAB}))$ and $20 \mu \mathrm{l}$ of proteinase $\mathrm{K}(10 \mathrm{mg} / \mathrm{ml})$.

118 Subsequently,300 $\mu \mathrm{l}$ of $20 \%$ [wt/vol] SDS was added, and incubated at $65{ }^{\circ} \mathrm{C}$ for $2 \mathrm{~h}$ with gentle

119 mixing every $15 \mathrm{~min}$. After $2 \mathrm{~h}$ of incubation samples were centrifuged at $6,000 \times \mathrm{g}$ for $10 \mathrm{~min}$ at

120 room temperature. The resulting supernatants were mixed with an equal volume of chloroform:

121 iso-amyl alcohol (24: 1, vol/vol). The aqueous phase was transferred to a new

122 tube after centrifugation at $6,000 \times \mathrm{g}$ for $10 \mathrm{~min}$. To the aqueous phase, 0.6 volume of iso-

123 propanol was added and the mixture was left at room temperature for $1 \mathrm{~h}$, followed by

124 centrifugation $(14,000 \times \mathrm{g}, 20 \mathrm{~min})$. Then, the DNA pellet was washed with ice-cold $70 \%$

125 (vol/vol) ethanol and resuspended in double-distilled water. Healthy and diseased coral

126 fragments were extracted separately. The integrity of the extracted DNA was verified by agarose 
127 gel electrophoresis. The concentration of extracted DNA was quantified using a NanoDrop ND-

1281000 spectrophotometer (Peqlab Biotechnologie GmbH, Erlangen, Germany).

129

130

131

132

133

134

135

136

137

138

139

140

141

142

143

144

145

146

147

148

\section{6s rRNA amplification and sequencing}

The purified metagenomic DNA was used as the template for amplification of the partial 16S rRNA gene using universal bacterial primers E785F (5'-GGATTAGATACCCTGGTAGTCC-3') and E1081R (5'-CTCACGRCACGAGCTGACG-3') encompassing the 5 and 6 hypervariable regions in prokaryotic $16 \mathrm{~S}$ rRNA gene. Each pair of primers was attached with a specific 8-bp barcode sequence at 5' end (Meyer et al., 2008) and used for amplification of each metagenomic DNA sample in order to generate tagged 16S rRNA amplicons. Polymerase chain reactions were performed using Phusion DNA polymerase (Thermo Scientific, Espoo, Finland) on a MyCycler thermocycler for 25 cycles of denaturation at $98^{\circ} \mathrm{C}$ for $10 \mathrm{sec}$, annealing at $69^{\circ} \mathrm{C}$ for $30 \mathrm{sec}$, and extension at $72^{\circ} \mathrm{C}$ for $30 \mathrm{sec}$. The amplicons were purified using QIAGEN PCR purification kit (QIAGEN, Hilden, Germany) and were quantified using NanoDrop ND-1000 Spectrophotometer (Thermo Fisher Scientific, Waltham, MA, USA). Three independent PCR amplicons obtained from the individual coral metagenomic sample were performed. Sequencing was done using the ION PGMTM platform (Life Technologies, Carlsbad, CA, USA) following the manufacturer's recommended protocols.

\section{Data cleaning and analyses}

Data analysis was done in QIIME version 1.9.1 (Caporaso et al., 2010) mainly for clustering sequences into operational taxonomic units (OTUs), classifying taxonomy and calculating diversity index. First, the raw sequences were initially demultiplexed into specific groups based on the tagged sequences and trimmed off low-quality score reads (Phred $\leq \mathrm{Q} 20$ ), barcodes, and 
149 primers. Chimeric sequences and amplification errors were filtered by UCHIME (Edgar et al.,

150 2011) using the referenced dataset from the Ribosomal Database Project (Cole et al., 2014). The

151 OTUs were clustered from the remaining sequences with an "open-reference" method using

152 UCLUST (Edgar, 2010) at 97\% similarity. The representative sequence of each cluster was

153 assigned for taxonomy against the Greengene database (McDonald et al., 2012). In order to

154 compare the diversity among the samples, alpha diversity index including observed OTUs,

155 Shannon-Weaver index, and the Chaol richness estimator was calculated using a cutoff of

15621,089 reads per sample, which was the minimal number of reads per sample obtained. The

157 difference of microbial communities among samples was measured using weighted UniFrac

158 distance (Lozupone et al., 2011) and Principal Coordinates Analysis (PCoA). The differences of

159 bacterial adundance, OTU number, and diversity index between healthy and infected corals were

160 statistically tested using White's non-parametric t-test (White et al., 2009) implemented in

161 STAMP (Parks et al., 2014).

\section{Results}

\section{Sample characterization}

164 Fragments of both healthy and diseased corals were collected from four major coral species in 165 the sea of Central Java, Indonesia. Physicochemical characteristics of seawater in the sampling 166 areas are described in Table 1. Both of the sampling sites have the same coral reef topology.

167 Those sites are covered by various coral species from many lifeforms, such as branching, massive, submassive and encrusting. The seawater in Ujung Gelam had slightly higher temperature $\left(30.1^{\circ} \mathrm{C}\right)$ and dissolved oxygen $(6.4 \mathrm{mg} / \mathrm{l})$ but with lower $\mathrm{pH}(7.3)$ and salinity $(32.0$ PSU) than that in Cemara Kecil $\left(28.3{ }^{\circ} \mathrm{C}, 6.2 \mathrm{mg} / 1,7.8\right.$, and $34.3 \mathrm{PSU}$, respectively). The 
171 diseased corals were affected by different diseases commonly found in the Indo-Pacific sea. The

172 physical appearances of the healthy and diseased corals are shown in Fig. 1 and Fig.S2. $A$.

173 aspera infected by white band disease (A. aspera-WBD) showed symptom with the appearance

174 of the white band between healthy and dead coral tissues. A. formosa infected by black band

175 diseases (A. formosa-BBD) showed lesion as a reddish to dark-colored band. Cyphastrea sp.

176 infected by yellow blotch disease (Cyphastrea sp.-YBD) which resulted in a band of yellow

177 tissue around the enlarging sediment patch. Isopora sp. infected by white plaque disease

178 (Isopora sp.-WPD) showed progressing band of bleached coral tissue followed by necrotic tissue 179 starting from the base of the branch.

180 Overview of sequencing dataset and alpha diversity analysis

181 The structures of bacterial communities associated with healthy and infected corals were

182 investigated based on 16s rRNA sequences analyzed by the ION PGM platform. A total of

$1831,788,418$ raw reads were obtained with an average read length of 260 base pairs. After the data

184 cleaning process, $89.25 \%$ of raw reads $(1,596,127$ reads) were obtained ranging from 21,453 to

185107,722 reads per sample. There was no significant difference of the average sequence number

186 obtained from individual coral species in healthy and infected stages (ANOVA; $>>0.05$ ). Total

187 numbers of sequencing read for all samples are presented in Table 2 and Table S1.

188 Analysis of microbial community by alpha and beta diversity suggested the inequality of

189 diversity among coral samples (Table 2). Overall, there was no significant difference in bacterial

190 diversity between the two sampling sites or among the coral species. According to QIIME, the

191 data set covered $96.8-99.1 \%$ of the bacterial diversity at $97 \%$ similarity. The number of OTUs at

192 the 97\% similarity ranged from 837 to 3,081 OTUs/ sample, which was lowest and highest in 
193 sample $A$. aspera (Aa-3) and Isopora sp. (Is-WPD-1), respectively. The highest total number of

194 OTUs was found in sample $A$. formosa (Af-1) $(4,440)$ while the lowest was observed in

195 Cyphastrea sp. (Cs-YBD-1) $(1,648)$ as estimated by the richness estimator, Chao1. In order to

196 reduce the bias of unequal number of reads among the individual samples, normalization was

197 performed by a subsampling method using a cutoff level of the minimal number of reads in an

198 individual sample obtained (21,089 reads). Shannon's diversity indexes from OTU table (97\%

199 similarity) indicated significantly reduced diversity of bacteria in the diseased $A$. formosa and

200 Cyphastrea $\mathrm{sp}$. than diseased ones (P-value $<0.05)$; however, there was no significant difference

201 in bacterial diversity between the healthy and diseased corals for species A. aspera and Isopora

202 sp. (P-value $>0.05)$ (Fig. 2A). The shared OTU analysis revealed that the number of common

203 OTUs in both healthy and diseased coral species ranging from 24.31-31.25\%. A substantial

204 fraction of OTUs in the healthy corals was replaced by newly introduced OTUs upon infection.

205 This resulted in the presence of unique OTUs related to causative or opportunistic bacteria in all

206 diseased corals, accounting for $28.78-49.51 \%$ of the total diversity of the coral-associated

207 bacteria in the diseased stage (Fig. 2B).

208 The coverage of the dataset to the total diversity was assessed by rarefaction curve as shown in

209 Fig. S3. For A. formosa and Cyphastrea sp., similar slopes were found for the healthy and

210 infected corals, suggesting saturation of OTUs from both groups. In contrast, the slopes for the

211 healthy A. aspera and Isopora sp. were substantially higher than that of the infected groups while

212 the higher variation of OTUs was found in the infected corals compared to the healthy corals.

213 The results thus suggested a high microbial adaptation of the bacteria associated with $A$. aspera

214 and Isopora sp. in the infected stage.

215 Taxonomic assignment of coral-associated microbial communities 
216 Taxonomic classification by QIIME revealed that totally 59 bacterial phyla, 190 orders, and 307

217 genera were assigned in coral metagenomes. Only a small fraction $(1.11 \%)$ of the total sequences

218 could not be classified into any known phyla and was labeled as an unassigned sequence.

219 According to the total dataset, the overall bacterial communities in the corals was dominated by

220 sequences affiliated to the phylum Firmicutes, followed by Proteobacteria and Bacteroidetes as

221 the major phyla across all samples, respective in their relative abundance, except in $A$. aspera

222 where these three phyla showed relatively balanced distribution. Other phyla including

223 Actinobacteria, Fusobacteria, and Lentisphaerae were present in lower abundances. Variation in

224 their relative abundance was found depending on coral species and health status (Fig. 3). At the

225 class level, Clostridia were a predominated class in Firmicutes while Delta- and

226 Gammaproteobacteria were majorly presented in phylum Proteobacteria in all coral samples,

227 except in Isopora sp.-WPD. Bacteroidia and Flavobacteria existed as a major class in

228 Bacteroidetes in all samples.

229 Comparative analysis based on coral's health status indicated that relative abundance of

230 Proteobacteria was markedly increased in diseased corals $A$. aspera-WBD (50.18\%) and

231 Isopora sp.-WPD (39.14\%) but slightly decreased in the other two coral species. With a higher

232 number of Delta- and Gammaproteobacteria in A. aspera-WBD compared to the healthy one, a

233 significantly decreasing number of Flavobacteria (from $14.48 \%$ to $2.44 \%$ ) in infected $A$. aspera-

234 WBD was clearly observed while an abundance of Clostridia was not significantly different (P-

235 value $>0.05$ ) in both healthy and infected groups. Higher relative abundances of Delta-, Epsilon-

236 and Gammaproteobacteria in Isopora sp.-WPD were observed in agreement with the reduction

237 of Clostridia when compared to the healthy corals. The ratio of Clostridia was significantly

238 higher in A. formosa -BBD and Cyphastrea sp.-YBD compared to the healthy ones. 
239 Focusing at the deeper taxonomic level, different relative abundances with significant variations

240 in some bacterial genus were observed depending on coral species and health status (Fig. 4).

241 Fusibacter belonging to phylum Firmicutes was predominantly present across all samples except

242 A. aspera-WBD, where Vibrio was a major genus with approximately two times higher than the

243 Fusibacter. This was related to the marked decreasing relative abundance of Fusibacter in $A$.

244 aspera-WBD along with a significantly increased ratio of Vibrio (and Acrobacter but not

245 significant). A lower number of Fusibacter in infected corals was also found in the Isopora sp.-

246 WPD, but the number of Vibrio was not changed significantly (P-value $>0.05$ ) regardless of the

247 coral health. Relative abundance of Arcobacter in class Epsilonproteobacteria was significantly

248 higher $(\mathrm{P}$-value $<0.05)$ in Isopora sp.-WPD but was not different in the other groups of diseased

249 coral. On the other hand, the amount of Fusibacter found in the A. formosa-BBD and Cyphastrea

250 sp.-YBD was higher than that found in the healthy ones (P-value $<0.05)$. This was associated

251 with the increase of genus WH1-8 within phylum Firmicutes in the A. aspera-WBD and Isopora

252 sp.-WPD samples.

\section{Correlation of bacterial diversity and beta diversity analysis}

254 The beta diversity of bacterial communities related to the coral health status was measured using

255 the weighted Unifrac method. Principal Coordinates Analysis (PCoA) based on weighted

256 distance metric indicated that the bacterial diversity in healthy and diseased coral samples were

257 clustered separately from each other for individual coral species (Fig. 5A). This suggested

258 alteration of bacterial diversity when the corals were infected by any of these diseases.

259 Distribution of bacteria was also clustered according to health status of corals regardless of the

260 coral species, i.e. clusters between (1) healthy $A$. formosa and Cyphastrea sp., (2) infected $A$.

261 formosa-BBD and Cyphastrea sp.-YBD, (3) healthy A. aspera and Isopora sp., and (4) infected 
262 A. aspera-WBD and Isopora sp.-WPD (Fig. 5B). Moreover, the result from PCoA plot conforms

263 to the UPGMA tree constructed from weighted UniFrac distances (Fig. 6). The UPGMA tree

264 topology showed clearly separated clusters between healthy and infected coral samples including

265 (1) healthy A. aspera and infected A. aspera-WBD, (2) healthy Isopora sp. and infected Isopora

266 sp.-WPD, and (3) healthy A. formosa, Cyphastrea sp. and infected A. formosa-BBD, Cyphastrea

267 sp.-YBD. As individual coral species used in this study displayed different symptoms of

268 diseases, the results suggested that when different coral species containing similar bacterial

269 profiles were infected with different diseases, bacterial communities tend to alter to the similar

270 direction. For example, bacterial profiles between A. formosa and Cyphastrea sp. were closed in

271 the health status. However, when they were infected by BBD (A. formosa-BBD) and YBD

272 (Cyphastrea sp.-YBD), bacterial communities in these two coral species were changed to the

273 same direction and clustered together.

274 Changes in bacterial diversity in the healthy and infected corals are shown by a box plot of

275 Phylogenetic Diversity (PD) Whole Tree. According to the results (Fig. S4), there is no

276 significant difference in bacterial diversity measured by PD between healthy and infected corals

277 (P-value $>0.05)$. Interestingly, the variation of PD values in diseased corals tended to be higher

278 than the healthy coral possibly because the diseased coral is more susceptible to colonization by

279 opportunistic bacteria. This was associated with higher or lower in diversity of the associated

280 bacteria. Infection of $A$. aspera with WBD resulted in a marked increase in diversity of the

281 bacterial communities. This situation was also observed in Isopora sp. and Isopora sp.-WPD.

282 Decrease in complexity of the communities was found in A. formosa-BBD and Cyphastrea sp.-

283 YBD. The results thus suggest alteration in the community structure of coral associated bacteria

284 upon infection. 


\section{Discussion}

286 Coral diseases are the result of complex interactions between host, causative agents, and

287 environment (Martin et al., 1987; Sunagawa et al., 2010). They are characterized by a shift in

288 microbial communities in coral mucus and tissue. However, causes and consequences of this

289 phenomenon to pathogenesis is usually not fully understood due to the complexity and dynamics

290 of the associated bacteria as well as effects of abiotic factors. According to our study, shifts in

291 bacterial communities were found in all taxonomic levels upon infection of all coral species by

292 all diseases. WBD is an important coral disease causing loss of corals in many regions of the

293 world. It has been reported to exhibit high host specificity, particularly Acropora species,

294 including A. cervicornis and A. palmata in the Caribbean (Kline \& Vollmer, 2011). Based on the

295 findings in our work, A. aspera showed a reduced diversity index for its associated bacteria upon

296 infection by WBD. This was related to the increasing abundance of all sub-phyla of

297 Proteobacteria along with the decreases in Firmicutes (Clostridia) and Bacteroidetes

298 (Flavobacteria) with the presence of Fusibacteria found only in the diseased stage. This

299 phenomenon occurred along with a significant increase in Vibrio and WH1-8 and decreasing

300 Fusibacter upon infection. The causative agent of WBD is currently unknown but has been

301 shown to possibly cause by bacteria according to a study on $A$. cerevicornis and $A$. palmata using

302 antibiotic treatment (Sweet et al., 2014). Vibrio spp. were consistently found in association with

303 both healthy and diseased corals (Cunning et al., 2008; Mouchka et al., 2010). Comparison of

304 bacterial diversity in healthy and WBD-infected A. palmata based on 16s rRNA showed

305 decreasing relative abundance of Betaproteobacteria and Actinomycetes with increasing

306 abundance of Planctomycetes and Cyanobacteria (Pantos \& Bythell, 2006). A putative pathogen

$307 V$. charcharii has been identified and partially proven as the causative agent for WBD type II 
308 based on Henle-Koch's postulate (Kline \& Vollmer, 2011). However, the causative bacteria for

309 WBD type I has not yet been identified.

$310 \mathrm{BBD}$ is a polymicrobial coral disease which is considered one of the most virulent disease of

311 scleractinian corals caused by polymicrobial factors which result in massive destruction of

312 framework-building corals worldwide. Although factors affecting susceptibility of corals to BBD

313 are still not fully understood, a few works showed that BBD pathogenesis is linked to nutrient

314 enrichment, elevated temperature and light intensity. A recent study on Caribbean corals showed

315 that the microbial communities in heathy corals were dominated by Gammaproteobacteria,

316 particularly Halomonas spp. while the microbiome of BBD consortia were more variable and

317 diverse (Meyer et al., 2017). Studies using a culture-independent molecular approach showed a

318 diverse microbial community classified into four functional groups, including photoautotrophs

319 (Cyanobacteria), sulfate-reducers (Desulfovibrio), sulfide oxidizers (Beggiatoa) and organo-

320 heterotropths (Vibrio) (Sere et al., 2016). Among them, Desulfovibrio spp. and Vibrio

321 coralliilyticus were suspected as the primary pathogens; however, without proven by Henle

322 Koch's postulate (Sere et al., 2016). Basically, the complex microbial consortia act to produce

323 highly concentrated sulfide specifically by the promoted Deltaproteobacteria under anoxic

324 conditions beneath the BBD mat that are lethal to coral tissue (Sato et al., 2017). The

325 accumulation of sulfide underneath the BBD mat was partially due to the lack of sulfur oxidizers

326 which contributes to the lethality of the disease (Meyer et al., 2017). Meta-analysis of published

327 clonal library studies of BBD microbial communities showed that, with few exceptions, the

328 microbial species composition of BBD communities did not correlate with the species of the host

329 corals with the domination of OTU of Roseofilum reptotaenium in over $70 \%$ of the samples 
330 (Miller \& Richardson, 2011). In addition, three OTUs of Bacteroidetes and Alpha-proteobacteria

331 were present in $13 \%$ of the samples with other OTUs found in $<7 \%$ of the samples.

332 According to our study, decreasing relative abundance of Proteobacteria, particularly the

333 subphyla Epsilon and Gammaproteobacteria, was found with increasing Firmicutes (Clostridia)

334 in the A. formosa-BBD. This was related to increasing abundance of Fusibacter and WH1-8

335 bacteria upon the infection. Increasing abundance of Fimicutes, Cytophaga-Flexibacter-

336 Bacteroidetes (CFB) and Deltaproteobacteria in the infectious mat was identified in a pioneered

337 molecular analysis work using Terminal Fragment Length Polymorphism (T-RFLP) (Frias-

338 Lopez et al., 2004). The results showed that the composition of the infectious bacterial mat was

339 not related to the species of coral being infected. Instead, differences in the mat composition

340 appear to be linked to the species of cyanobacteria dominant in the infection. However, the

341 presence of cyanobacteria in $A$. formosa-BBD could not be detected due to the specificity of

342 primers used for amplification (Nübel et al., 1997). No increase in Desufovibrio was observed in

343 the 16S rRNA sequencing analysis of $A$. formosa-BBD in this study. According to a previous

344 study (Meyer et al., 2016), Desulfovibrioprofundus which is thought to be responsible the

345 production of $\mathrm{H}_{2} \mathrm{~S}$ was detected in only $5 \%$ of the clone libraries analyzed. These discrepancies

346 could be due to technical issues (e.g. amplification biases and low coverage of microbiome in

347 clonal libraries), seasonal and/or regional differences in the BBD composition or function-based

348 (rather than taxonomic-based) of the BBD community. Variations have been detected in bacterial

349 communities associated across geographical regions and between sympatric coral species (Sere

350 et al., 2016). High variability in the BBD bacterial communities in different geographical areas

351 and coral species suggested that this disease derives from an earlier infection, which aids

352 subsequent infection of opportunistic microorganisms such as cyanobacteria (Sere et al., 2016). 
353 Recent analysis of metageomes from Caribbean and Pacific BBD mat revealed five

354 metagenome-assembled genomes of Roseofilum, Proteobacteria and Bacteroidetes which are

355 proposed to play symbiotic interaction (Meyer et al., 2017). However, the mechanisms of BBD

356 development remain unclear, and no primary pathogens have yet been identified. The difference

357 on the results observed in this study to previous works could be due to the difference of

358 environmental factors such as climatic condition and location (Mouchka et al., 2010).

359 YBD infection in corals resulted in a decrease in microbial diversity index in Cyphastrea sp..

360 This was along with reduction in the relative abundance of Proteobacteria and Bacteroidetes

361 (Cytophaga) and increase in Firmicutes (Bacilli) along the infection. Vibrio alginolyticus has

362 been identified as a causative agent for YBD (Cervino et al., 2004b). Four Vibrio species ( $V$.

363 rotiferianus, $V$. harveyi, $V$. alginolyticus, and $V$. proteolyticus) were identified as causative

364 agents in YBD in Caribbean corals through a series of infection and isolation experiments

365 (Cervino et al., 2004b; Cunning et al., 2008). It is suggested that this Vibrio consortium infected

366 the coral's symbiotic algae and resulted in degradation of zooxanthellae leading to the pale-

367 yellow bands observed on infected Caribbean and Indo-Pacific corals (Cervino et al., 2008;

368 Cunning et al., 2008). However, the pathogenesis mechanism during YBD infection is still

369 poorly understood. A survey of Vibrio species associated with healthy corals and YBD infected

370 corals were conducted using a culture-based approach (Cunning et al., 2008). The results showed

371 a shift from isolates taxonomically affiliated with $V$. fortis dominate in healthy corals to those

372 related to $V$. harveyi, a known marine pathogen in diseased corals. However, this study did not

373 find any Vibrio species that are always present in YBD lesion but not in healthy corals. Although

374 Vibrio have been reported as pathogenic bacteria for various coral diseases, it should be noted

375 that they are a part of common bacterial taxa found in coral microbiomes (Bourne \& Munn, 
376

377

378

379

380

381

382

383

384

385

386

387

388

2005; Daniels et al., 2011; Gray et al., 2011; Nithyanand \& Pandian, 2009). The higher overall abundance of Vibrio in the healthy corals than the infected corals as found in our study could be expected due to the taxonomic refinement of the partial rDNA sequence was analyzed to the genus level only, not specifically to the specific group of pathogenic Vibrio species. The conflicting phenomenon on the higher abundance of Vibrionales in healthy corals has been previously reported in analysis of symbioints in corals infected by WPD (Cardenas et al., 2012; Kellogg et al., 2013).

WPD has been reported to affect more than 40 coral species (Sunagawa et al., 2009; Weil et al., 2006). However, identification of its causative agent is still problematic, suggesting a complex etiological phenomenon involving alterations in the dynamic interaction between environmental factors, and symbiotic microbiomes. According to our study, reduction in the relative abundance of all subphyla of Proteobacteria was found in Isopora sp. upon infection by WPD with increasing abundance of Firmicutes (Clostridia) and changes in the phylum Bacteroidetes with decreasing Cytophaga and increasing Flavobacteria along with reduction in Lentispaheria. This change in the bacterial community structure led to an increase in Acrobacter and WH1-8 bacteria along with the decrease in Clostridia and Fusibacter at the genus level. Increasing diversity and a shift in bacterial community structure in Montastraea faveolata infected by WPS Type II has been shown using high-density 16s rRNA gene microarray and clone library sequencing (Sunagawa et al., 2009). Accumulation of various known bacterial families known as coral pathogens including Alteromonadaceae and Vibrionaceae has been found. However, the primary pathogen Aurantimonas corallicida (Denner et al., 2003) previously proven by Koch's postulate was not detected in this molecular study (Sunagawa et al., 2009). Analysis of differentially abundant OTUs in Caribbean coral species Orbicella faceolata and O. franksi showed marked 
399

400

401

402

403

404

405

406

407

408

409

410

411

412

413

414

415

416

417

418

419

420

differences in bacterial communities in the heathy and diseased coral samples but not between coral species (Sunagawa et al., 2010). The subsequent comparison in Indo-Pacific coral species (Pavonaduerdeni and Poriteslutea) showed distinct bacterial community patterns associated with ocean basin, coral species and health status. Increasing bacterial richness was found in the diseased samples suggesting the role of opportunistic bacteria during pathogenesis. These studies showed microbial community patterns related to WPD that are consistent over coral species and oceans, irrespective of the putative underlying pathogens (Sunagawa et al., 2010). This includes various taxa involving Proteobacteria, Bacteroidetes, Cyanobacteria, and Firmicutes. A higher abundance of known coral pathogens, e.g. Alteromonadaceae, Rhodobacteraceae, and Vibrionaceae have been reported in Pavona duerdeni and Porites lutea infected by WPD using 16S rRNA gene microarray (Roder et al., 2014). A significant increase in Alphaproteobacteria and a concomitant decrease in the Beta- and Gammaproteobacteria were also observed in WPDaffected reef-building corals Diploriastrigose and Siderastrea sidereal using culture-dependent methods and pyrosequencing of 16s rRNA sequences (Cardenas et al., 2012). Significant shifts were also found for the orders Rhizobiales, Caulobacteriales, Burkhoderiales, Rhodobacteriales, Aleteromonadales, and Xanthomonadales, suggesting roles of these bacteria on pathogenesis.

\section{Conclusion}

Our findings showed structural alteration of microbiomes associated with important reef-building corals in Indonesian sea revealed by a culture-independent molecular analysis approach. Coral disease pathogenesis led to disturbance of the complex microbial communities and shifts in the overall bacterial community structures as shown by well separated clustering of the heathy and infected coral microbiomes with significant changes in certain key bacterial species. This study 
421 provides insights on understanding the functions of associated symbiont bacteria in pathogenesis.

422 Further in-depth analysis on the role of microbiomes on coral health is warrant.

\section{Acknowledgement}

424 The authors would like to thank Dr. Philip J. Shaw for manuscript proofreading and comments. 
426

427

428

429

430

431

432

433

434

435

436

437

438

439

440

441

442

443

444

445

446

\section{References}

Blackall, L.L., Wilson, B., van Oppen, M.J. 2015. Coral-the world's most diverse symbiotic ecosystem. Mol Ecol, 24(21), 5330-47.

Bourne, D.G., Garren, M., Work, T.M., Rosenberg, E., Smith, G.W., Harvell, C.D. 2009. Microbial disease and the coral holobiont. Trends Microbiol, 17(12), 554-62.

Bourne, D.G., Munn, C.B. 2005. Diversity of bacteria associated with the coral Pocillopora damicornis from the Great Barrier Reef. Environ Microbiol, 7(8), 1162-74.

Brodersen, K.E., Lichtenberg, M., Ralph, P.J., Kuhl, M., Wangpraseurt, D. 2014. Radiative energy budget reveals high photosynthetic efficiency in symbiont-bearing corals. $J R S o c$ Interface, 11(93), 20130997.

Burriesci, M.S., Raab, T.K., Pringle, J.R. 2012. Evidence that glucose is the major transferred metabolite in dinoflagellate-cnidarian symbiosis. J Exp Biol, 215(Pt 19), 3467-77.

Caporaso, J.G., Kuczynski, J., Stombaugh, J., Bittinger, K., Bushman, F.D., Costello, E.K., Fierer, N., Pena, A.G., Goodrich, J.K., Gordon, J.I., Huttley, G.A., Kelley, S.T., Knights, D., Koenig, J.E., Ley, R.E., Lozupone, C.A., McDonald, D., Muegge, B.D., Pirrung, M., Reeder, J., Sevinsky, J.R., Turnbaugh, P.J., Walters, W.A., Widmann, J., Yatsunenko, T., Zaneveld, J., Knight, R. 2010. QIIME allows analysis of high-throughput community sequencing data. Nat Methods, 7(5), 335-6.

Cardenas, A., Rodriguez, R.L., Pizarro, V., Cadavid, L.F., Arevalo-Ferro, C. 2012. Shifts in bacterial communities of two Caribbean reef-building coral species affected by white plague disease. ISME J, 6(3), 502-12. 
447 Cervino, J.M., Hayes, R.L., Goreau, T.J., Smith, G.W. 2004a. Zooxanthellae regulation in yellow 448 blotch/band and other coral diseases contrasted with temperature related bleaching: in situ destruction vs expulsion. Symbiosis, 37, 63-85.

450

451

452

453

454

455

456

457

458

459

460

461

462

463

464

465

466

467

468

469

Cervino, J.M., Hayes, R.L., Polson, S.W., Polson, S.C., Goreau, T.J., Martinez, R.J., Smith, G.W. 2004b. Relationship of Vibrio species infection and elevated temperatures to yellow blotch/band disease in Caribbean corals. Appl Environ Microbiol, 70(11), 6855-64.

Cervino, J.M., Thompson, F.L., Gomez-Gil, B., Lorence, E.A., Goreau, T.J., Hayes, R.L., Winiarski-Cervino, K.B., Smith, G.W., Hughen, K., Bartels, E. 2008. The Vibrio core group induces yellow band disease in Caribbean and Indo-Pacific reef-building corals. $J$ Appl Microbiol, 105(5), 1658-71.

Cesar, H., Burke, L., Pet-Soede, L. 2003. The Economics of Worldwide Coral Reef Degradation. Cesar Environmental Economics Consulting (CEEC).

Cole, J.R., Wang, Q., Fish, J.A., Chai, B., McGarrell, D.M., Sun, Y., Brown, C.T., Porras-Alfaro, A., Kuske, C.R., Tiedje, J.M. 2014. Ribosomal Database Project: data and tools for high throughput rRNA analysis. Nucleic Acids Res, 42(Database issue), D633-42.

Cunning, J.R., Thurmond, J.B., Smith, G.W., Weil, E., Ritchie, K.B. 2008. A survey of Vibrios associated with healthy and Yellow Band diseased Montastraea faveolata. Proceedings of the 11th international coral reef symposium, 206-210.

Daniels, C.A., Zeifman, A., Heym, K., Ritchie, K.B., Watson, C.A., Berzins, I., Breitbart, M. 2011. Spatial heterogeneity of bacterial communities in the mucus of Montastraea annularis. Marine Ecology Progress Series, 426, 29-40.

Denner, E.B., Smith, G.W., Busse, H.J., Schumann, P., Narzt, T., Polson, S.W., Lubitz, W., Richardson, L.L. 2003. Aurantimonas coralicida gen. nov., sp. nov., the causative agent of 
white plague type II on Caribbean scleractinian corals. Int J Syst Evol Microbiol, 53(Pt 4),

471 1115-22.

472

473

474

475

476

477

478

479

480

481

482

483

484

485

486

487

488

489

490

491

Edgar, R.C. 2010. Search and clustering orders of magnitude faster than BLAST. Bioinformatics, 26(19), 2460-1.

Edgar, R.C., Haas, B.J., Clemente, J.C., Quince, C., Knight, R. 2011. UCHIME improves sensitivity and speed of chimera detection. Bioinformatics, 27(16), 2194-200.

Frias-Lopez, J., Klaus, J.S., Bonheyo, G.T., Fouke, B.W. 2004. Bacterial community associated with black band disease in corals. Appl Environ Microbiol, 70(10), 5955-62.

Gignoux-Wolfsohn, S.A., Vollmer, S.V. 2015. Identification of Candidate Coral Pathogens on White Band Disease-Infected Staghorn Coral. PLoS One, 10(8), e0134416.

Gray, M.A., Stone, R.P., McLaughlin, M.R., Kellogg, C.A. 2011. Microbial consortia of gorgonian corals from the Aleutian islands. FEMS Microbiol Ecol, 76(1), 109-20.

Harvell, D., Jordán-Dahlgren, E., Merkel, S., Rosenberg, E., Raymundo, L., Smith, G., Weil, E., Willis, B. 2007. Coral disease, environmental drivers, and the balance between coral and microbial associates. Oceanogr, 20(1), 172-195.

Hughes, T.P., Baird, A.H., Bellwood, D.R., Card, M., Connolly, S.R., Folke, C., Grosberg, R., Hoegh-Guldberg, O., Jackson, J.B., Kleypas, J., Lough, J.M., Marshall, P., Nystrom, M., Palumbi, S.R., Pandolfi, J.M., Rosen, B., Roughgarden, J. 2003. Climate change, human impacts, and the resilience of coral reefs. Science, 301(5635), 929-33.

Kanokratana, P., Chanapan, S., Pootanakit, K., Eurwilaichitr, L. 2004. Diversity and abundance of bacteria and archaea in the Bor Khlueng hot spring in Thailand. J Basic Microbiol, 44(6), $430-44$. 
492 Kellogg, C.A., Piceno, Y.M., Tom, L.M., DeSantis, T.Z., Gray, M.A., Zawada, D.G., Andersen, 493 G.L. 2013. Comparing Bacterial Community Composition between Healthy and White 494 495 Plague-Like Disease States in Orbicella annularis Using PhyloChip ${ }^{\mathrm{TM}}$ G3 Microarrays. PLoS One, 8(11), e79801.

496

497

498

499

500

501

502

503

504

505

506

507

508

509

510

511

512

513

514

Kline, D.I., Vollmer, S.V. 2011. White Band Disease (type I) of endangered caribbean acroporid corals is caused by pathogenic bacteria. Sci Rep, 1,7 .

LaJeunesse, T.C., Parkinson, J.E., Gabrielson, P.W., Jeong, H.J., Reimer, J.D., Voolstra, C.R., Santos, S.R. 2018. Systematic revision of Symbiodiniaceae highlights the antiquity and diversity of coral endosymbionts. Curr Biol, 28, 2570-2580.

Lozupone, C., Lladser, M.E., Knights, D., Stombaugh, J., Knight, R. 2011. UniFrac: an effective distance metric for microbial community comparison. ISME J, 5(2), 169-72.

Martin, S.W., Meek, A.H., Willeberg, P. 1987. Veterinary Epidemiology Principles and Methods. Iowa State University Press.

McDonald, D., Price, M.N., Goodrich, J., Nawrocki, E.P., DeSantis, T.Z., Probst, A., Andersen, G.L., Knight, R., Hugenholtz, P. 2012. An improved Greengenes taxonomy with explicit ranks for ecological and evolutionary analyses of bacteria and archaea. ISME J, 6(3), 610-8.

Meyer, J.L., Gunasekera, S.P., Scott, R.M., Paul, V.J., Teplitski, M. 2016. Microbiome shifts and the inhibition of quorum sensing by Black Band Disease cyanobacteria. ISME J, 10(5), 1204-16.

Meyer, J.L., Paul, V.J., Raymundo, L.J., Teplitski, M. 2017. Comparative Metagenomics of the Polymicrobial Black Band Disease of Corals. Front Microbiol, 8, 618.

Meyer, M., Stenzel, U., Hofreiter, M. 2008. Parallel tagged sequencing on the 454 platform. Nat Protoc, 3(2), 267-78. 
515 Miller, A.W., Richardson, L.L. 2011. A meta-analysis of 16S rRNA gene clone libraries from the 516 polymicrobial black band disease of corals. FEMS Microbiol Ecol, 75(2), 231-41.

517 Mouchka, M.E., Hewson, I., Harvell, C.D. 2010. Coral-associated bacterial assemblages: current 518 knowledge and the potential for climate-driven impacts. Integr Comp Biol, 50(4), 662-74.

519 Nithyanand, P., Pandian, S.K. 2009. Phylogenetic characterization of culturable bacterial diversity associated with the mucus and tissue of the coral Acropora digitifera from the Gulf of Mannar. FEMS Microbiol Ecol, 69(3), 384-94.

522

523

524

525

526

527

528

529

530

531

532

533

534

535

536 cyanobacteria. Appl Environ Microbiol, 63(8), 3327-3332.

Pantos, O., Bythell, J.C. 2006. Bacterial community structure associated with white band disease in the elkhorn coral Acropora palmata determined using culture-independent 16S rRNA techniques. Dis Aquat Organ, 69(1), 79-88.

Parks, D.H., Tyson, G.W., Hugenholtz, P., Beiko, R.G. 2014. STAMP: statistical analysis of taxonomic and functional profiles. Bioinformatics, 30(21), 3123-4.

Pootakham, W., Mhuantong, W., Putchim, L., Yoocha, T., Sonthirod, C., Kongkachana, W., Sangsrakru, D., Naktang, C., Jomchai, N., Thongtham, N., Tangphatsornruang, S. 2018. Dynamics of coral-associated microbiomes during a thermal bleaching event. Microbiologyopen, 7(5), e00604.

Radjasa, O.K., Vaske, Y.M., Navarro, G., Vervoort, H.C., Tenney, K., Linington, R.G., Crews, P. 2011. Highlights of marine invertebrate-derived biosynthetic products: their biomedical potential and possible production by microbial associants. Bioorg Med Chem, 19(22), 6658-74. 
537 Roder, C., Arif, C., Bayer, T., Aranda, M., Daniels, C., Shibl, A., Chavanich, S., Voolstra, C.R.

538 2014. Bacterial profiling of White Plague Disease in a comparative coral species $539 \quad$ framework. ISME J, 8(1), 31-9.

540 Rosenberg, E., Ben-Haim, Y. 2002. Microbial diseases of corals and global warming. Environ $541 \quad$ Microbiol, 4(6), 318-26.

542 Rosenberg, E., Koren, O., Reshef, L., Efrony, R., Zilber-Rosenberg, I. 2007. The role of 543 microorganisms in coral health, disease and evolution. Nat Rev Microbiol, 5(5), 355-62.

544 Sato, Y., Ling, E.Y., Turaev, D., Laffy, P., Weynberg, K.D., Rattei, T., Willis, B.L., Bourne, D.G. 545 2017. Unraveling the microbial processes of black band disease in corals through integrated $546 \quad$ genomics. Sci Rep, 7, 40455.

547 Schloss, P.D., Handelsman, J. 2005. Metagenomics for studying unculturable microorganisms: $548 \quad$ cutting the Gordian knot. Genome Biol, 6(8), 229.

549 Sere, M., Wilkinson, D.A., Schleyer, M.H., Chabanet, P., Quod, J.P., Tortosa, P. 2016. 550 Characterisation of an atypical manifestation of black band disease on Porites lutea in the 551 Western Indian Ocean. PeerJ, 4, e2073.

552 Sheridan, C., Kramarsky-Winter, E., Sweet, M., Kushmaro, A., Leal, M.C. 2013. Diseases in coral 553 aquaculture: causes, implications and preventions. Aquaculture, 396-399, 124-135.

Sokolow, S. 2009. Effects of a changing climate on the dynamics of coral infectious disease: a 555 review of the evidence. Dis Aquat Organ, 87(1-2), 5-18.

Sunagawa, S., DeSantis, T.Z., Piceno, Y.M., Brodie, E.L., DeSalvo, M.K., Voolstra, C.R., Weil, 557 E., Andersen, G.L., Medina, M. 2009. Bacterial diversity and White Plague Disease558 559 associated community changes in the Caribbean coral Montastraea faveolata. ISME J, 3(5), 512-21. 
560 Sunagawa, S., Woodley, C.M., Medina, M. 2010. Threatened corals provide underexplored $561 \quad$ microbial habitats. PLoS One, 5(3), e9554.

562 Sweet, M.J., Croquer, A., Bythell, J.C. 2014. Experimental antibiotic treatment identifies potential 563 pathogens of white band disease in the endangered Caribbean coral Acropora cervicornis. Proc Biol Sci, 281(1788), 20140094.

567

Wegley, L., Edwards, R., Rodriguez-Brito, B., Liu, H., Rohwer, F. Metagenomic analysis of the microbial community associated with the coral Porites astreoides. Environ Microbiol, 9(11), 2707-2719.

Weil, E., Smith, G., Gil-Agudelo, D.L. 2006. Status and progress in coral reef disease research. Dis Aquat Organ, 69(1), 1-7.

White, J.R., Nagarajan, N., Pop, M. 2009. Statistical methods for detecting differentially abundant features in clinical metagenomic samples. PLoS Comput Biol, 5(4), e1000352.

572 Wilkinson, C. 2008. Status of coral reefs of the world: 2008. Global Coral Reef Monitoring 573 Network and Reef and Rainforest Research Centre., Townsville, Australia.

574 Woo, S., Yang, S.H., Chen, H.J., Tseng, Y.F., Hwang, S.J., De Palmas, S., Denis, V., Imahara, Y., 575 Iwase, F., Yum, S., Tang, S.L. 2017. Geographical variations in bacterial communities 576 associated with soft coral Scleronephthya gracillimum. PLoS One, 12(8), e0183663.

577 Zhou, J., Bruns, M.A., Tiedje, J.M. 1996. DNA recovery from soils of diverse composition. Appl 578 Environ Microbiol, 62(2), 316-22. 


\section{Table 1 (on next page)}

Sampling locations and sea water characteristics. 
1 Table 1: Sampling locations and sea water characteristics

\begin{tabular}{|c|c|c|c|c|c|c|}
\hline $\begin{array}{l}\text { Sampling } \\
\text { location }\end{array}$ & $\begin{array}{c}\text { Temperature } \\
\left({ }^{\circ} \mathrm{C}\right)\end{array}$ & pH & $\begin{array}{c}\text { Salinitya }^{\mathrm{a}} \\
\text { (PSU) }\end{array}$ & $\begin{array}{c}\text { Dissolve } \\
\text { oxygen } \\
\text { (mg/l) }\end{array}$ & $\begin{array}{l}\text { Turbidity } \\
\text { (m) }\end{array}$ & $\begin{array}{c}\text { Collected coral } \\
\text { name }\end{array}$ \\
\hline $\begin{array}{l}\text { Ujung gelam } \\
\text { (S0549'57.7", } \\
\text { E110²2'50.5") }\end{array}$ & $30.1 \pm 0.4$ & $7.3 \pm 0.1$ & $32.0 \pm 0.4$ & $6.4 \pm 0.6$ & $5 \pm 0$ & Acropora formosa \\
\hline $\begin{array}{l}\text { Cemara Kecil } \\
\text { (S05'50'12.9", } \\
\left.\text { E110 } 25^{\circ} 14.1 "\right)\end{array}$ & $28.3 \pm 0.2$ & $7.8 \pm 0.1$ & $34.3 \pm 0.3$ & $6.2 \pm 0.3$ & $2 \pm 0$ & $\begin{array}{l}\text { Acropora aspera } \\
\text { Cyphastrea sp. } \\
\text { Isopora sp. }\end{array}$ \\
\hline
\end{tabular}

2 aractical salinity unit

3

4 


\section{Table 2 (on next page)}

Diversity estimates of bacterial 16S rRNA gene in sequencing datasets of microbial communities associated with healthy and infected corals. 
1 Table 2: Diversity estimates of bacterial 16S rRNA gene in sequencing datasets of microbial communities 2 associated with healthy and infected corals

\begin{tabular}{|c|c|c|c|c|c|c|c|}
\hline Coral species & Sampling site & Condition & Sample ID & $\begin{array}{c}\text { No. of } \\
\text { sequences } \\
\text { after QC }\end{array}$ & $\begin{array}{c}\text { Observed } \\
\text { OTUs }\end{array}$ & Chao1 & Shannon \\
\hline \multirow{6}{*}{$\begin{array}{l}\text { Acropora } \\
\text { aspera }\end{array}$} & \multirow{6}{*}{ Cemara Kecil } & \multirow[t]{3}{*}{ Healthy } & Aa-1 & 102,886 & 1,732 & 3,096 & 5.5581 \\
\hline & & & $\mathrm{Aa}-2$ & 70,966 & 1,386 & 2,666 & 5.1340 \\
\hline & & & Aa-3 & 24,556 & 837 & 1,913 & 5.0301 \\
\hline & & \multirow{3}{*}{$\begin{array}{l}\text { Infected with } \\
\text { white band } \\
\text { disease }\end{array}$} & Aa-WBD-1 & 61,634 & 2,249 & 3,609 & 5.9713 \\
\hline & & & Aa-WBD-2 & 107,722 & 1,948 & 3,337 & 5.4652 \\
\hline & & & Aa-WBD-3 & 27,701 & 1,363 & 2,539 & 6.1005 \\
\hline \multirow{6}{*}{$\begin{array}{l}\text { Acropora } \\
\text { formosa }\end{array}$} & \multirow{6}{*}{ Karimunjawa } & \multirow[t]{3}{*}{ Healthy } & Af-1 & 94,076 & 2,431 & 4,440 & 6.0624 \\
\hline & & & Af-2 & 88,344 & 2,300 & 4,177 & 6.0045 \\
\hline & & & Af-3 & 27,979 & 1,344 & 2,474 & 6.3581 \\
\hline & & \multirow{3}{*}{$\begin{array}{l}\text { Infected with } \\
\text { black band } \\
\text { disease }\end{array}$} & Af-BBD-1 & 65,206 & 1,740 & 3,434 & 5.4460 \\
\hline & & & Af-BBD-2 & 73,163 & 2,222 & 4,401 & 5.5205 \\
\hline & & & Af-BBD-3 & 21,453 & 1,140 & 2,568 & 5.6828 \\
\hline \multirow{6}{*}{$\begin{array}{l}\text { Cyphastrea } \\
\text { sp. }\end{array}$} & \multirow{6}{*}{ Cemara Kecil } & \multirow[t]{3}{*}{ Healthy } & Cs-1 & 55,264 & 1,793 & 3,479 & 6.1171 \\
\hline & & & Cs-2 & 33,475 & 1,376 & 2,958 & 5.9524 \\
\hline & & & Cs-3 & 77,176 & 2,212 & 3,764 & 6.2162 \\
\hline & & \multirow{3}{*}{$\begin{array}{l}\text { Infected with } \\
\text { yellow blotch } \\
\text { disease }\end{array}$} & Cs-YBD-1 & 23,850 & 925 & 1,648 & 5.3805 \\
\hline & & & Cs-YBD-2 & 63,703 & 1,987 & 3,769 & 5.5155 \\
\hline & & & Cs-YBD-3 & 56,042 & 1,704 & 3,533 & 5.2922 \\
\hline \multirow{6}{*}{ Isopora sp. } & \multirow{6}{*}{ Cemara Kecil } & \multirow[t]{3}{*}{ Healthy } & Is-1 & 55,471 & 1,592 & 3,324 & 5.6822 \\
\hline & & & Is-2 & 103,771 & 2,033 & 3,611 & 5.6433 \\
\hline & & & Is-3 & 102,458 & 2,252 & 3,555 & 6.0461 \\
\hline & & \multirow{3}{*}{$\begin{array}{l}\text { Infected with } \\
\text { white Plaque } \\
\text { disease }\end{array}$} & Is-WPD-1 & 89,080 & 3,081 & 3,849 & 6.8630 \\
\hline & & & Is-WPD-2 & 78,463 & 1,965 & 3,305 & 6.1575 \\
\hline & & & Is-WPD-3 & 91,688 & 2,026 & 3,541 & 6.0657 \\
\hline
\end{tabular}

3 
Figure 1

Appearance of coral specimens in healthy and infected stages; $(A)$ black band disease, (B) white band disease, (C) white plaque disease, (D) yellow blotch disease.
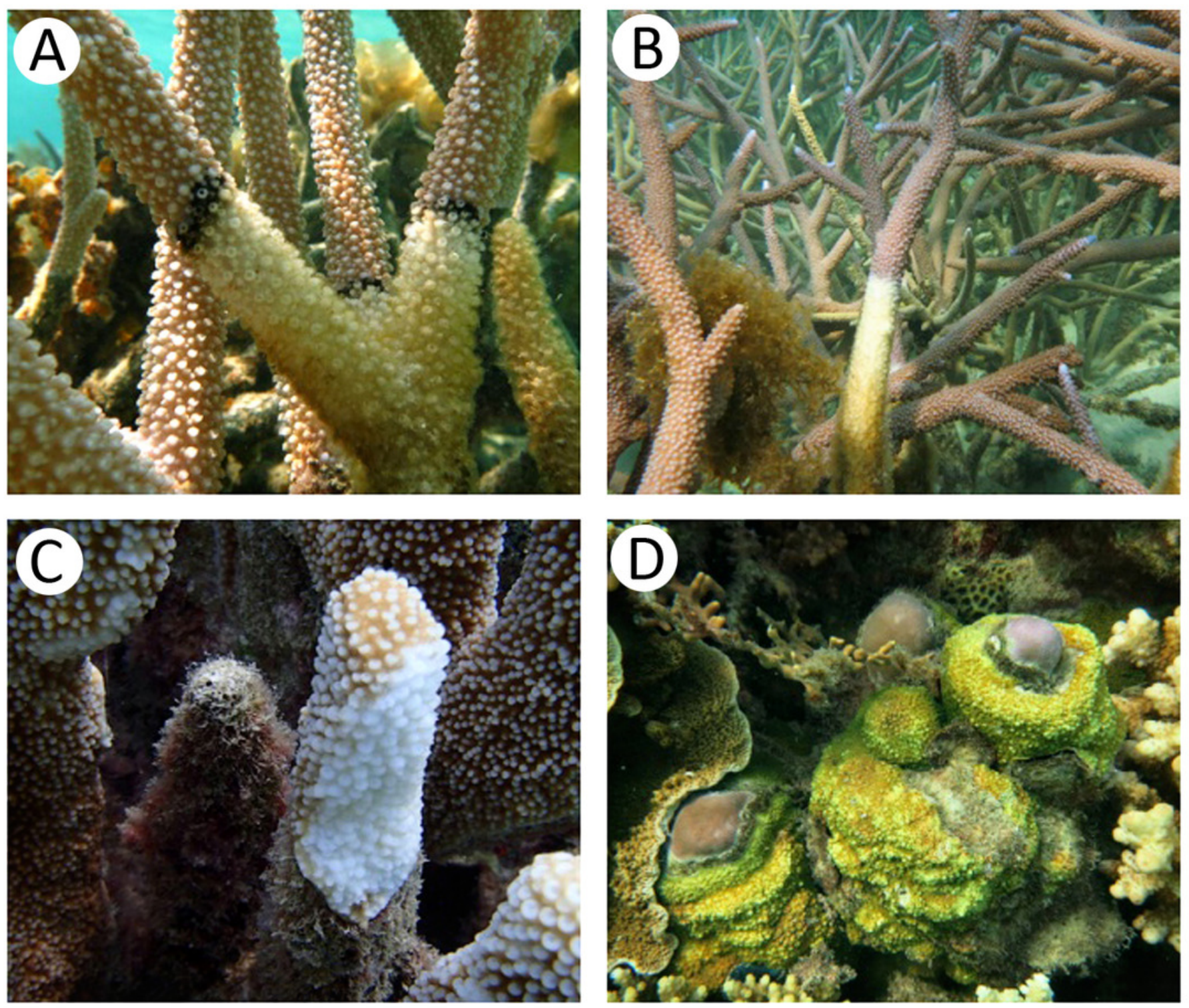


\section{Figure 2}

Comparison of Shannon's diversity indexes (A) and number of shared/unique OTUs (B) between healthy and infected conditions in each coral species.

Coral species marked with asterisk represented significant difference (White's nonparametric t-test) between healthy and infected corals.
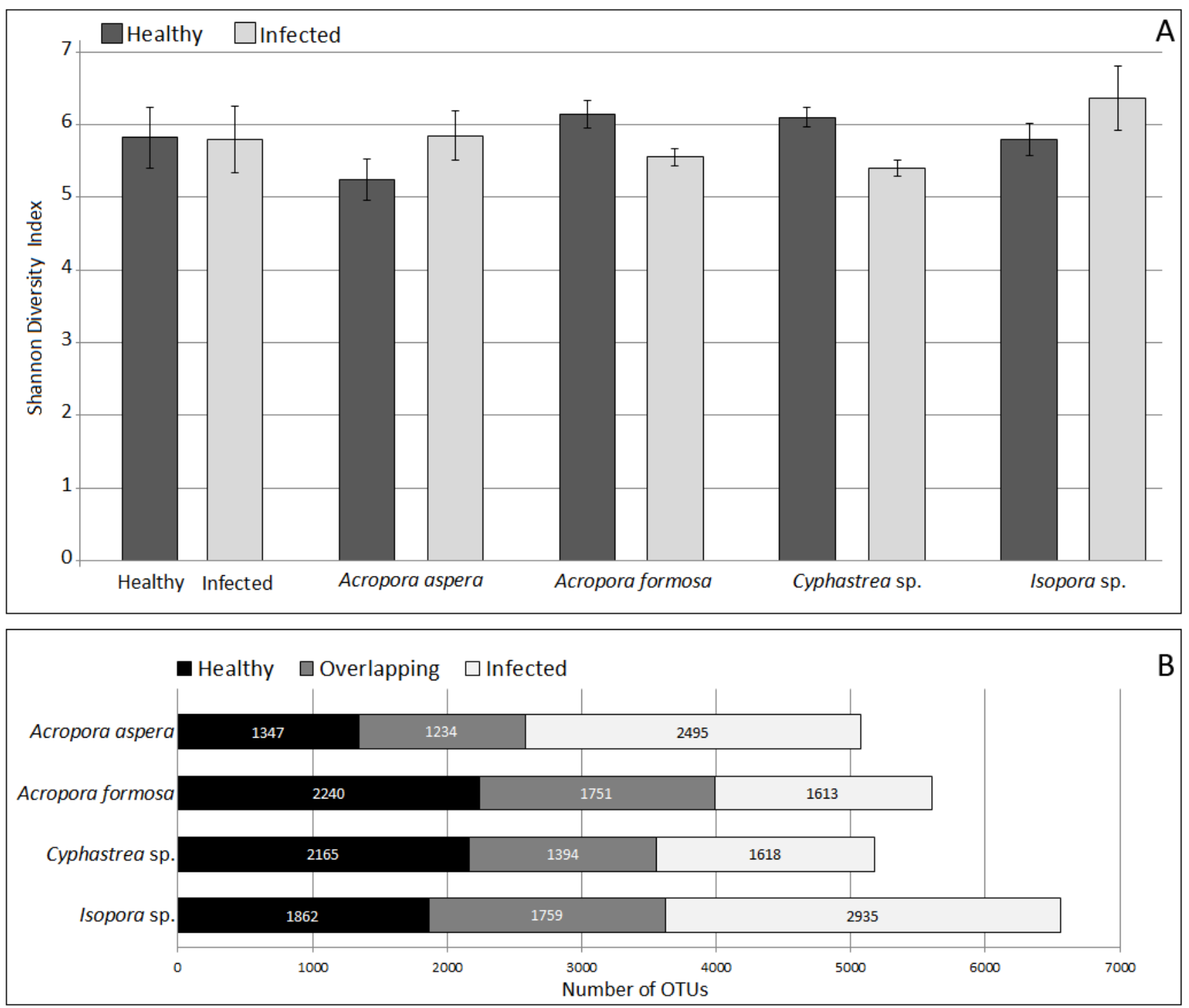


\section{Figure 3}

Relative abundance of bacterial distribution profiles at class level within the coral metagenomic samples obtained from healthy and diseased coral specimens.

Bacterial taxa labelled with coral species; Aa, Af, Cs, and Is indicated significantly difference (White's non-parametric t-test) between healthy and infected corals.

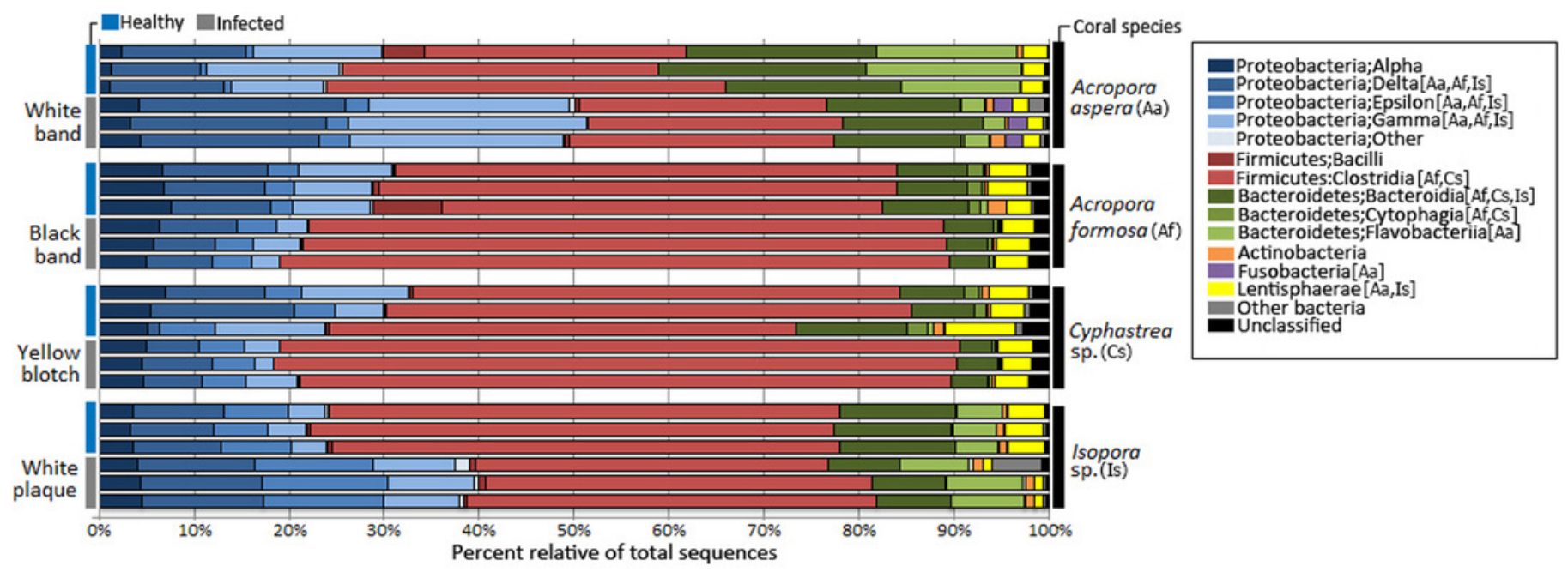


Figure 4

Taxonomic classification of bacterial diversity at the genus level.

Major bacterial genera were selected and shown as (A) a heat map based on the coral species and their health status and $(B-E)$ difference in mean proportions healthy and infected corals.

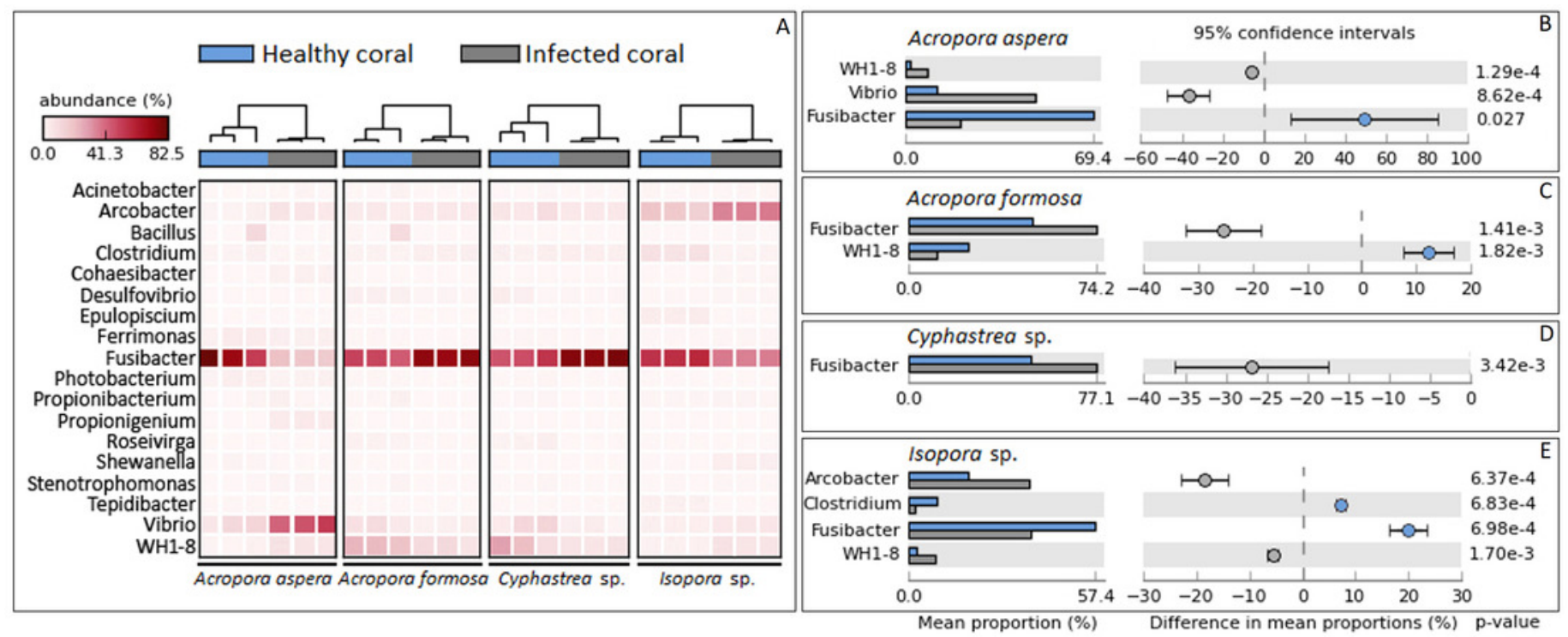


Figure 5

Weighted UniFrac PCoA plot showing the differences between bacterial communities based on $(A)$ the coral health status and $(B)$ coral species.
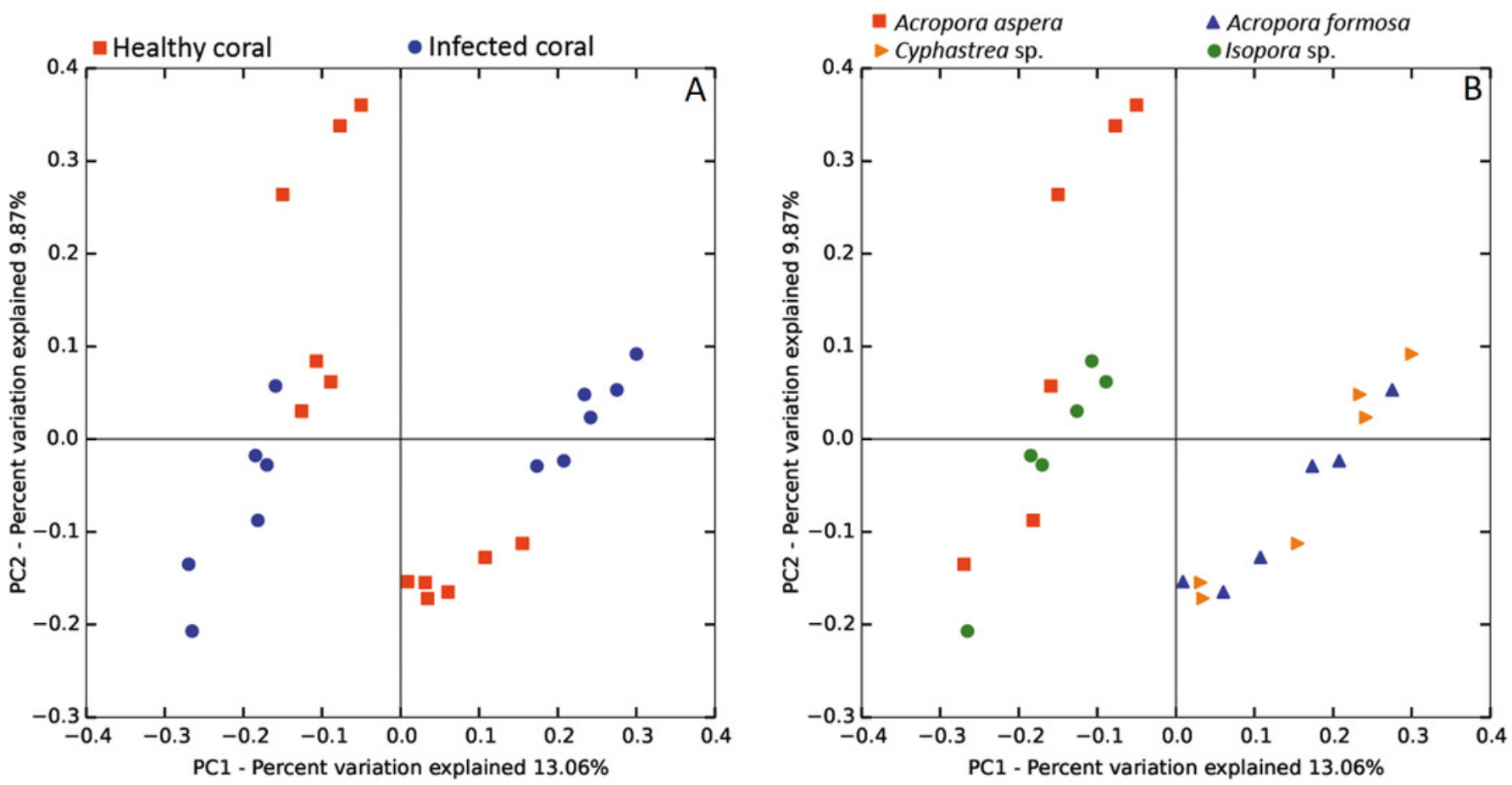
Figure 6

Jackknifed UPGMA tree of all coral samples based on weighted UniFrac distance matrix.

The jackknifed bootstrapped tree was illustrated with internal nodes colored; red for $75-100 \%$ support, yellow for $50-75 \%$, green for $25-50 \%$, and blue for $<25 \%$ support. 
Aa: Acropora aspera |WBD: White band disease

\section{Af: Acropora formosa |BBD: Black band diseases}

Cs: Cyphastrea sp. | YBD: Yellow blotch disease

Is: Isopora sp. | WPD: White plaque disease

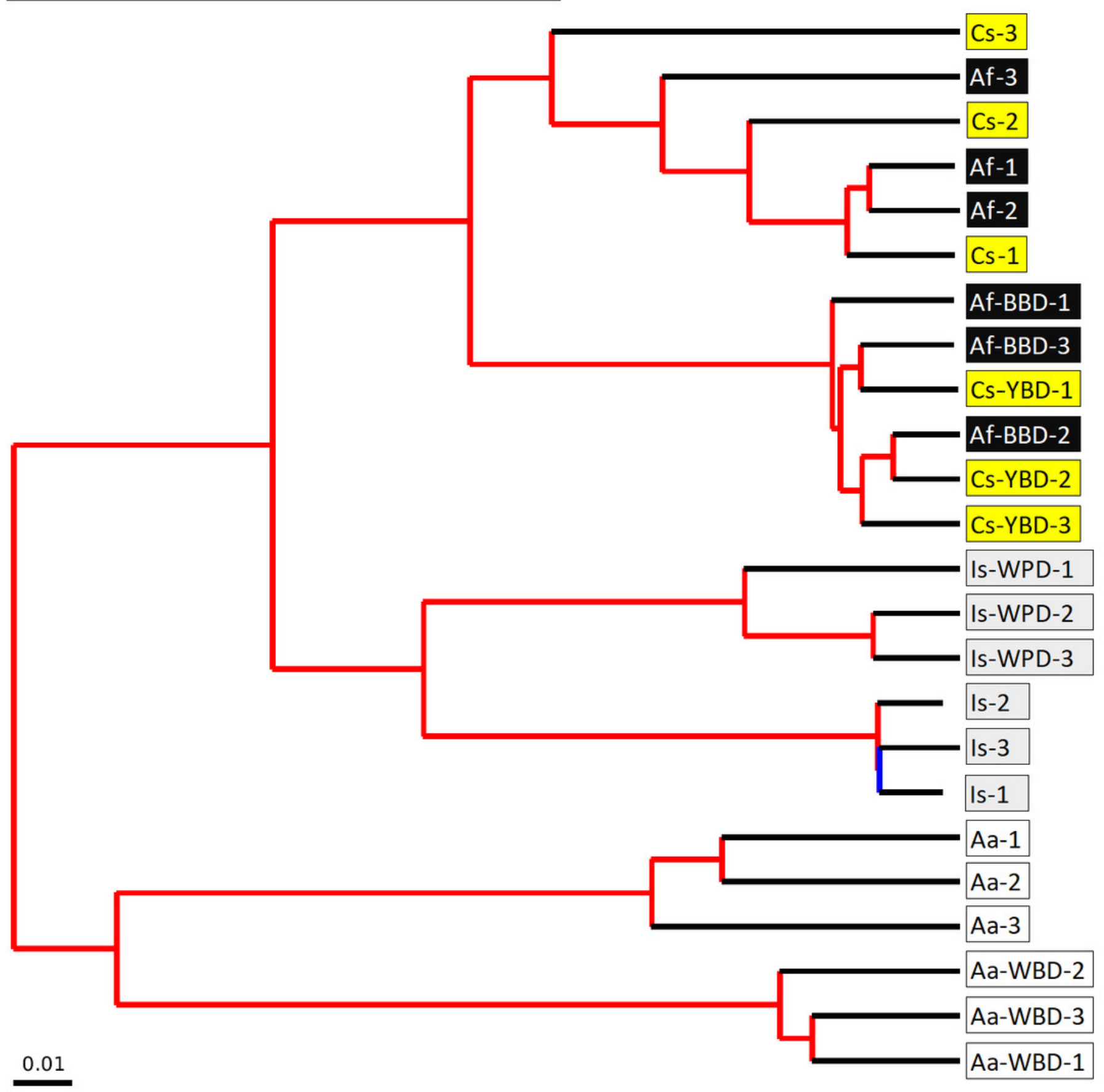

